\title{
Adoption of Sustainable Retrofit in UK Social Housing $2010-2015$
}

\section{Introduction}

In 2010 a survey was conducted to assess the adoption of sustainable retrofit in the UK social housing sector, investigating issues of strategic attitudes and readiness (Swan et al., 2013a) and the adoption of sustainable retrofit technologies (Swan et al., 2013b). This survey of 130 social housing providers provided insight into their attitudes during a period when retrofit of the domestic sector was being heavily supported as a solution to the UK's energy "trilemma"; climate change, fuel poverty and energy security. During the 5 years since the survey, a number of policy changes have taken place that apply directly to energy and buildings, but also the social housing sector. The purpose of the 2013 and 2015 follow up surveys has been to identify the transition for the sector across these three points and reflect on how these changes may influence social housing professionals' attitudes to the retrofit agenda. This research follows on from the findings presented in Swan et al. (2013a), where the adoption of specific retrofit technologies and their perceived effectiveness were explored. The objective of this element of the study was to track adoption and changing perceptions of retrofit technologies over the period of the study.

The UK's housing stock accounts for $29 \%$ of total energy demand, with a large proportion of this, 62\%, being used for space heating (Palmer and Cooper, 2013). In viewing energy consumption as a "trilemma" (Department of Trade and Industry, 2003), domestic retrofit can impact three main policy objectives. In terms of reducing carbon dioxide emissions, which remains an obligation under the Climate Change Act (HM Government, 2008), both reduction in energy demand or more widespread deployment of renewables at the domestic level can have an impact. At the time of the survey in 2013, this remained a priority. However, changes to the UK Building Regulations, leading to the removal of the zero carbon target, which was defined through the Code for Sustainable Homes (McLeod et al., 2012), indicated a possible change in position in terms of UK Government priorities. Fuel poverty, which had a change in definition between 2010 and 2013, remained a priority during this period. The previous definition, as championed by Boardman (Boardman, 2010), where if more than $10 \%$ of income was used to heat the property to $21^{\circ} \mathrm{C}$ in the living room and $18^{\circ} \mathrm{C}$ elsewhere, as outlined in the assumptions of the Standard Assessment Procedure (SAP), then the household was viewed to be in fuel poverty. This was changed under the Hills Review (Hills, 2012), away from this $10 \%$ rule to a more complex model based on the median level of fuel costs and residual income in relation to the poverty line. This approach has been criticised as being equally as problematic as the previous $10 \%$ rule (Walker and Day, 2012; Moore, 2012). Energy security focuses on the consistency of supply, this can be viewed as either a technical problem, or one of politics, given the fact that primary fuels are supplied in an international market. Energy security may also be considered within the concept of energy efficiency's contribution to the reduction of the demand side of the equation, a 
concept sometimes presented as "negawatts" (Lovins, 1996). Energy security is perhaps the least tangible aspect of the 'trilemma' for those concerned with the retrofitting of social housing.

The response to reducing energy consumption within housing, and social housing in particular, was to consider upgrading the existing stock. With replacement rates at less than $1 \%$ per annum, a number of authors identified the existing stock would need to be addressed to make a difference to energy consumption, due to the high percentage of existing stock, approximately 65$80 \%$, that would be standing in 2050 (Kelly, 2010; Power, 2008; Ravetz, 2008). This meant that sustainable retrofitting of the existing properties would be required. The literature uses a range of terms; modernisation, retrofit and refurbishment are all used to describe the upgrade of a property to improve its energy efficiency (Bell and Lowe, 2000; Hong et al., 2006; Jenkins, 2010; Kelly, 2009; Reeves et al., 2010). As with the previous survey we will discuss sustainable retrofit as upgrades to the fabric or systems of a property to improve its energy efficiency (Swan et al., 2013b).

In 2010, both the outgoing Labour UK Government (HM Government, 2010a) and the incoming Coalition Government (HM Government, 2010b) both commissioned reports identifying domestic retrofit as a key priority that would be piloted within the social housing sector. The initial survey was conducted during a period of what might be considered a positive policy environment towards energy efficiency in the social housing sector. The impact of this can be seen in the high rates of deployment highlighted in the national home energy efficiency database (HEED). The second and third surveys were conducted in a changing policy environment, under the UK Coalition Government, with major transitions in both the position of energy efficiency and policies within the social housing sector.

The Bonfield Review, or Each Homes Counts (2016) has recently been published outlining a series of high level recommendations for consultation with regards to energy efficiency in the wider domestic sector. While the focus is predominately focused on private sector housing there are a number of issues that are specifically pertinent to the findings of the survey. The importance of social housing to the sector is again highlighted,

"Housing Associations have a key role to play in the delivery of energy efficiency and renewable energy installations at scale for low income and vulnerable residents as part of wider home improvement programmes." (Bonfield, 2016, p58)

The changes to UK energy efficiency policy and related changes to housing policy provide a shifting backdrop to decisions made by housing professional with regards to technical choices for sustainable retrofit.

\section{UK Social Housing Stock and Energy Efficiency}

In 2010, retrofit as a central policy goal to address the energy consumption of the housing stock was well recognised by both the outgoing Labour 
Government in the Warm Homes, Greener Homes Strategy (HM Government, 2010a), and the incoming Coalition Governments Low Carbon Construction Report (HM Government, 2010b). Over the period of the 3 surveys, the social housing stock had been a major focus of a number of different policy instruments. While not all of the instruments were aimed solely at the social housing stock, many of them did have an impact on the sector.

One of the major changes during the period studied was the transition of the supplier obligation from the Carbon Emissions Reduction Target (CERT) (Jenkins, 2010), aimed at reducing carbon dioxide emissions, and the Communities Energy Saving Programme (CESP) (Reeves et al., 2009), which sought to encourage community wide deployment of retrofit interventions. In 2012/13 this transitioned to the Energy Company Obligation, which had three components, carbon emissions reduction, fuel poverty and communities (Rosenow and Eyre, 2012; Tovar, 2012). During 2013, a political discussion with regards to fuel poverty led the carbon emissions reduction element of the ECO to be substantively cut. While this was not solely directed at social housing, it may have had an impact, as ECO was used to gap fund retrofit schemes. The changes to the ECO also saw the end of the Warm Front Scheme in 2013 (Critchley et al., 2007), which was replaced by the fuel poverty element of the ECO.

While not specifically targeted at social housing, (Booth and Choudhary, 2013), the Green Deal (Guertler 2012), did indicate a shift from subsidy driven approaches for retrofitting the housing stock to more a more market-led approach. The programme was based on a building assessment, which would identify retrofit improvements. These improvements would then have their upfront cost covered, to be paid back over the life of the improvements through a charge on the electricity meter. This payment remained with the property rather than the individual. However, this approach was unsuccessful with the Green Deal finance being withdrawn in 2015, leading to a critical report from the National Audit Office (NAO, 2016). Guertler et al. (2013) conducted a scathing critique of the policy, blaming issues such as lack of clarity in the policy, overambitious targets, issues with repayment projections, credit costs and poor engagement with consumers, for the policy's failure, criticisms echoed by Rosenow and Eyre (2016). Some of the issues with the Green Deal led to the development of a supporting subsidy, known as the Green Deal Home Improvement Fund (O'Keeffe et al., 2016), which was a finite pot to be drawn down to support Green Deal installations. Again, while not directly focused on social housing, it was possible for tenants to apply with agreement from their landlord.

When considering retrofit improvements to social housing it is also worth considering directly funded programmes. Funding such as the European Regional Development Fund (ERDF) was used by regions to address fuel poverty in the social housing stock, such as Arbed in Wales (De Laurentis et al., 2016). In addition, directly funded programmes through the Department of Energy and Climate Change were also used to target social housing. The Go Early Core Cities Programme (DECC, 2011) was designed to support the Green Deal, with a programme targeted at core cities (Dixon and Wilson, 
2014), such as Birmingham, Leeds and Manchester. These predominately focused, although not entirely, on social housing; for example, Greater Manchester delivered 608 homes in total, with 83 private homes and 525 socially rented properties (Association of Greater Manchester Authorities, 2013). This was followed by the Green Deal Communities Scheme (DECC, 2013), which was launched in 2013. This was a competitive grant scheme for areas to undertake subsidised retrofit work, but with a greater focus on the wider housing stock. Currently, there are no final evaluations for this programme, so the impact on social housing is not clear although, anecdotally, there appears to have still been a substantial element of social housing within these programmes.

The period under review, $2010-2015$, has been described as "problematic" from a policy perspective (Mallaburn and Eyre, 2014) due in no small part to changes brought about by austerity. The mixture of approaches, with many policies acting alongside each other seems to have created a confusing picture of grant funding, supplier obligation and policy innovation that does not appear to have worked well for the wider housing sector. However, potentially due to its ability to act as a "professional" consumer (Jenkins, 2010), social housing appears to have benefited from these programmes over the longer period. The social housing stock has the highest energy efficiency of any tenure, with an average SAP rating of 67 , when compared to 59 for private rented and owner occupied properties in 2014/15 (DCLG, 2016). However, it should be noted that this is not a new phenomenon. Looking back to 2008 in data from the English Housing Survey, we can see that the gap between the EPC ratings for social housing and owner occupied housing has narrowed over recent years from a peak of 11.1 points in 2009 to 7.4 points in 2014 . Historical data indicates this is a gap that has persisted since 1996, where the data was first collected as part of the English House Condition Survey.

Also pertinent, particularly to the most recent 2015 survey, is that the social housing sector was subject to a number of policy changes that had the potential to shift the priorities away from the existing stock to addressing other issues. Greater pressures to increase the supply of new affordable homes (Jacobs \& Manzi, 2013) combined with changes to payments in housing benefits and an imposed 1\% reduction in rental income from April 2016 through to 2020 (Taylor-Gooby, 2012), has no doubt had an effect on many social housing providers resources and capacity to deliver retrofit. Much of this increased Government intervention has potentially been influenced by the Office for National Statistics decision in October 2015 to reclassify registered providers of social housing in England as being public sector, thus placing $£ 60$ bn of social housing debt on to the Government's balance sheet and providing a Government impetus to limit and control any future borrowing.

\section{Methodology}

The survey design follows the rationale and approach laid out in Swan et al. (2013b). The aim of the wider study was to address the attitudes of social housing professionals with regards to energy efficiency in their stock. A panel of social housing professionals identified key constructs that led to the 
development of the items to ensure internal validity (Robson, 2002) in item design. The survey was self-completed with 37 items that included a range of Lickert, fixed and open questions delivered on-line with a small prize for participation each time. There were some additional questions that were added between the phases, however, the core questions under discussion here remained the same and would not be expected influence the results. Specifically, those that investigate the adoption and perception of effectiveness by social housing property professionals of specific retrofit technologies in their stock.

The Retrofit State of the Nation survey has been conducted over three phases 2010, 2013 and 2015. In 2010, the survey was distributed to a fixed mailing list of 704 social housing contacts. In 2013 and 2015 the approach was broader, with more partner databases and websites used to publicise the survey. However, this did mean that sample sizes for contacts were not possible to identify. It should also be considered that the 2015 survey was conducted prior to the commissioning of a major review, the Each Home Counts Review (Bonfield, 2016) (otherwise known as the Bonfield Review), which was designed to overhaul the policy with regards to domestic energy efficiency in all tenures.

Table 1 shows the sample sizes and response rates. It is identified that the 2013 survey had a far lower response rate than the 2010 or 2015 surveys. It was viewed this may have been due to a trade magazine running a similar survey during the data collection period.

The sample is not reflective of the total stock of social housing (Table 2). During the three phases of the study there were minor changes to the overall population of housing providers. The statistical data returns to the Homes and Communities Agency for this period (HCA, 2012, 2015) indicate that $80 \%$ of social housing providers owned less than 1000 units, while $54.5 \%$ of the stock is owned by $4.5 \%$ of providers, although there is a general trend indicated by the data that from 2007 larger providers have increased due to consolidation between some providers. As highlighted in Swan et al. (2013b) it was felt by the advisory panel that the sample was more representative of those social housing providers who would engage with retrofit through structured asset management programmes to deliver meaningful retrofit on their stock.

The regional distribution of responses, as shown in Table 3, was established by individual organisations identifying the regions in which they worked. This allowed for providers to identify multiple regions if they operated at a national level. In 2013 and 2015, Wales and Scotland were added, although responses were low from these regions.

The responses by region were noted in the 2010 survey to be lower than expected for London and the South East, when compared with the Homes and Communities data. This was repeated when the survey was rerun in 2013. However, in 2015, when the survey was administered through RE:NEW, a Mayor of London based initiative, the skew was reversed. This may have implications for the findings. 


\section{Main Findings}

The purpose of the previous paper was to investigate the adoption, and perceived effectiveness, of specific technologies within the social housing sector. While it is recognised that the whole house model is an essential component of retrofit (EST and TSB, 2009), it is clear that an understanding of the adoption and effectiveness of individual technologies has a role to play. It should be noted that in 2015, this question was specifically addressed. When respondents were asked about whole house retrofit solutions as an active priority, $13 \%$ of respondents stated they were actively developing or delivering a whole house approach. A further $61 \%$ stated they were interested in whole house retrofit, but were not actively engaging in this approach. This may indicate that individual measure led policies such as ECO may have an influence on whole house retrofit decision-making.

\section{Levels of Adoption}

Table 4 shows the levels of adoption for individual technologies over the period of the surveys. As would be expected, there has been an increase of adoption, defined as where a provider has experience of the technology, over the period. It should be noted that the question identifies whether a specific technology has been applied, rather than considering the proliferation through the stock.

As shown in Figure 1, many of the major technologies have nearly $100 \%$ adoption, specifically around loft, cavity and solid wall insulation. Loft insulation and cavity wall insulation, sometimes called soft measures, due to their ease of installation, were strongly driven by CERT (Howard, 2015), hence their major take up in 2010. It is estimated that 2.6 million homes received cavity wall and 3.9 million homes received loft insulation. Solid wall insulation was made available under CESP, which was designed to promote a whole house approach on a street-by-street basis. $81 \%$ of these communitybased projects had some element of solid wall insulation (Dowson et al., 2012). However, by 2013 , this had grown rapidly to $81 \%$ and then was $100 \%$ by 2015. This shift is potentially driven by the 2012 transition from CERT and CESP to the ECO, which had a greater focus on solid wall insulation (Rosenow et al., 2013). Other fabric solutions, such as draught stripping and thermally efficient doors and windows also had high take up. Draught stripping has a relatively low cost and is therefore easy to implement, while window replacement could be considered as part of general asset management, which may go some way to explaining the increase in these measures. Overall, this does seem to reflect that a fabric first (Taylor et al., 2013) approach, albeit supported by grants, has been adopted by the social housing sector.

Renewables such as photovoltaics and solar thermal saw large increases over the period, with PV, particularly, increasing in levels of adoption. This is almost certainly driven by the Feed in Tariff in established in 2010 (Muhammad-Sukki et al., 2013), which was responsible for 28,608 
installations in the first year alone (Smith, et al., 2014). Anecdotally, for social housing this often took the form of "rent a roof" schemes, where external companies would claim the feed in tariff for a fixed period in return for the provision of "free" installations, or social housing providers directly accessing the subsidy themselves. As with PV, solar thermal also saw large increases, largely driven by the introduction of the Renewable Heat Incentive (RHI) (Muhammad-Sukki et al., 2013), which covered a range of renewable heat technologies for, initially, the non-domestic sector and later the domestic sector. Proportionally, the increases are slower and overall adoption is lower as of 2015. The RHI was put in place 3 years after the Feed in Tariff and only available in a domestic context in 2014 (Snape, et al., 2015), and as social housing has a limited number of properties with roofs that are appropriate for solar thermal and PV, the early adoption of PV may have limited the opportunities for new solar thermal installs. Solar thermal, providing hot water and photovoltaics (PV), providing electricity, are both roof mounted technologies relying on energy from solar radiation and may represent something of a trade-off for social housing providers. Additionally, the widespread installation of combi boilers, which led to removal of hot water tanks, which are required for solar thermal, may have also limited opportunities for installs. Solar thermal was a more popular technology prior to the introduction of the Feed in Tariff (Balcombe et al., 2013), but it appears during the surveyed period that PV became far more popular.

It is also likely that the $\mathrm{RHI}$ has driven the adoption of ground source and air source heat pumps, both of which are eligible under the scheme. Both of these technologies saw a significant increase in adoption over the 5-year period. However, air source heat pumps, and to a lesser extent ground source, saw the greatest increase in adoption between 2010 and 2013, so the reasons for this increase is not entirely clear. It is possible that some of these technologies were supported through programmes such as the Renewable Heat Premium Payment (Abu-Bakar et al., 2013), launched in 2011, which was specifically targeted at social housing. However, as the survey only addresses the adoption rather than the proliferation of a technology, experimental installations may also be reported in this data, rather than technologies with fair higher proliferation such as solid wall insulation. It is possible that this view is also taken for two other $\mathrm{RHI}$ eligible technologies, biomass boilers and combined heat and power (CHP) systems, as both saw significant increases in adoption in 2013, prior to the availability of the $\mathrm{RHI}$ in the domestic context.

The introduction of grade A appliances, specifically boilers, was driven by previous supplier obligations and also supported by the ECO, as a part of the affordable warmth strand, known as the Home Heating Cost Reduction Obligation (HHCRO) (Stewart \& Dhesi, 2016). This is also supported by asset management schemes that will replace boilers as part of both planned cyclical replacement works and also responsive repairs and maintenance in social housing.

The other major point of interest is the adoption of mechanical ventilation and heat recovery (MVHR). As identified the modelling work by Jenkins (2010), 
MHVR would be required for properties where airtightness has been addressed to ensure effective ventilation. The period 2010-2015, saw a large increase in adoption, suggesting a possible increase in the requirement to address ventilation in retrofit properties.

\section{Perceived Effectiveness}

As stated in the previous paper (Swan et al., 2013a), effectiveness is a complex issue that is difficult to directly address in a wide-ranging survey. Sustainable retrofit can address many issues for social housing providers, such as fuel poverty (Jenkins, 2010), comfort of residents, carbon emissions targets and energy efficiency. Considered more widely, it has the potential to protect rental arrears, improve asset or rental value or impact the health of residents (Liddell and Morris, 2010). This, to some extent has been identified in the study in terms of the drivers for retrofit. In 2015, by far the largest driver to undertake retrofit was fuel poverty ( $83 \%$ of respondents). Climate change represented only $16 \%$ of answers. This did not represent a major change from 2010 , with climate change identified by $16 \%$ of respondents as a driver, while $88 \%$ identified fuel poverty or reducing fuel costs for tenants. This potentially identifies energy efficiency in terms of impact on residents as the main performance led criteria.

Another area of complexity with the concept of effectiveness, is an understanding of how respondents understood the performance of their stock. The issue of performance gap, where properties do not perform as expected when compared to models is a major issue for both new build properties and retrofit, which can be driven by technical (Calì et al., 2016) or human factors (Galvin, 2014). Measuring performance in the field is difficult (Swan et al., 2015) and can be costly. Understanding in situ performance does appear to be taking place; in 2015 an additional question was added to identify the level of monitoring activity (Table 5). This identified that only $20 \%$ of the sample had undertaken no evaluation of any sort, with the majority of evaluation around energy consumption (56\%) and resident surveys (58\%), although $38 \%$ did state that they had monitored individual measures. While the actual approaches of monitoring are not clear, it appears there is some level of evaluation taking place, potentially as a requirement to support the business case.

While the survey question does show that the importance of monitoring is recognised by a majority of the respondents, with only a minority having undertaken no evaluation whatsoever, it is not clear as to the full extent or detail of some of these approaches. It does, however, give some indication that the evaluations of effectiveness made by some of the respondents have some basis in evidence. This indicates the potential for a more qualitative study with the sector to understand how effectiveness is determined and measured.

The issue of performance gap is further compounded by the fact that models, commonly the Standard Assessment Procedure (SAP) or Reduced Data SAP, 
to which real performance is compared often have weaknesses in predicting actual energy use (Wetherell and Hawkes, 2011).

As with the previous studies, effectiveness of each technology was identified using the scale

$1-$ not all effective

2 - ineffective

3 - neither effective nor ineffective

4 - effective

5 - highly effective

Table 6 identifies the responses across the three phases of the study and includes the standard deviation to show agreement among the sample. The smaller sample size in 2013 may lead to some skewing the data.

Considering the change from $2010-2015$, as shown in Figure 2, we can see the following issues. The fabric solutions of loft and cavity, doors and windows and draft stripping all remained relatively consistent over the period, with the respondents viewing these as highly performing technologies. The standard deviations within the sample show a consistent spread of across the 3 phases of the study, which indicates a limited change in the spread of views from the respondents. Loft and cavity were generally seen as the most effective interventions, while other fabric measures were seen as mildly effective. The only fabric solution that indicates a change is solid wall insulation, which seems to have suffered a slight decline in terms of perceived effectiveness, moving from 3.96 down to 3.49 , which may be viewed as only mildly effective. This should be considered in light of emerging evidence of unintended consequences, such as overheating, mould, damp, rot, and air quality, with some solid wall installations, which were highlighted in the UK Building Research Establishment review of evidence (BRE, 2014) and identification of issues recommendations (BRE, 2016).

When we consider heat pumps, air source heat pumps saw a decline of 0.52 in perceived effectiveness to 2.78 , while ground source saw a more significant decline of 1.00 to 2.65 , meaning both of these technologies are broadly considered to be neither effective nor ineffective. This means that heat pumps are viewed as the least effective of the technologies, with the exception of biomass, which has seen an increase in adoption, as well as an increase in perceived effectiveness to 2.65. The survey does not differentiate between types of heat pumps, such as air to water or exhaust air, which may lead to different experiences.

PV and solar thermal seem to have polarised slightly in terms of perceived effectiveness; PV has seen a slight increase in perceived effectiveness, while solar thermal has declined, meaning PV is viewed as effective, while solar thermal is more neutral.

Overall, perceived effectiveness seems to be driven by familiarity. Many of the fabric options represent those technologies that are considered most 
effective. Of the mechanical and electrical solutions, only PV and energy efficient gas boilers are viewed as effective. Heat pumps, MVHR and biomass are generally viewed as neutral, neither effective nor ineffective.

None of the changes of position can be viewed as radical. While many of the respondent organisations were the same, given the time period, many of the individuals who responded for a specific company were different, making it difficult to track changes in position by specific individuals. While adoption, as might be expected, has become more widespread, there is still some ambivalence about a number of technologies even with increased familiarity. The survey will be repeated in the future and this may reflect further changes in views over time.

\section{Conclusions}

The Retrofit State of the Nation study was initiated in 2010 when the social housing sector was identified as a potential test bed for understanding retrofit technology. What can be seen from the data is that in terms of reach many of the technologies identified have been applied by the vast majority of the sector to some degree. This experience, however, has not necessarily led to an increased comfort with the technology, with opinions hardening between 2010 and 2015. Some of this may be driven by the fact that some technologies have taken time to generate understandable outcomes during this period or that with wider adoption there has been a slight hardening of opinion around certain technologies, particularly mechanical and electrical retrofit technologies.

The Bonfield Review identifies an issue that has specific relevance for the survey. The recognition that all technologies are not the same. The grouping of technologies into categories that appear to be based on a mixture of market penetration and risk, indicates the view of risk and retrofit is becoming better understood by the wider sector. These groupings, while not fully explained, appear to replicate the views of the respondents, particularly in the later surveys.

Energy consumption in housing remains an issue, although the policy focus appears to be moving to fuel poverty and away from carbon dioxide emissions. Social housing appears to remain an important part of the retrofit story and, as we enter a new policy phase, understanding what this actually means for retrofit activity within the sector will be important. However, energy policy and social housing are one part of the picture; responses will be in the context of wider social housing policy. It is possible that wider social housing policy changes may cause retrofit to be reprioritised in a way that the aspirations for social housing's role within the Bonfield Review may be confounded.

\section{References}

Abu-Bakar, S. H., Muhammad-Sukki, F., Ramirez-Iniguez, R., Mallick, T. K., McLennan, C., Munir, Abdul Rahim, R. (2013), "Is Renewable Heat Incentive 
the future", Renewable and Sustainable Energy Reviews, Vol. 26, pp. 365378.

Association of Greater Manchester Authorities (2013) Moving Towards the Green Deal: 'Go Early' success in Greater Manchester, AGMA, Manchester, UK.

Balcombe, P., Rigby, D., and Azapagic, A. (2013). Motivations and barriers associated with adopting microgeneration energy technologies in the UK. Renewable and Sustainable Energy Reviews, Vol. 22, pp. 655-666.

Bell, M. and Lowe, R. (2000), "Energy efficient modernisation of housing: A UK case study", Energy and Buildings, Vol. 32, No. 3, pp. 267-280.

Boardman, B. (2010), Fixing fuel poverty: challenges and solutions. Earthscan, New York, NY.

Booth, A.T. and Choudhary, R. (2013), "Decision making under uncertainty in the retrofit analysis of the UK housing stock: Implications for the Green Deal", Energy and Buildings, Vol. 64, pp. 292-308.

Bonfield, P. (2016), Each Homes Counts: An Independent Review of Consumer Advice, Protection, Standards and Enforcement for Energy Efficiency and Renewable Energy, Department for Business Innovation and Skills, London.

Building Research Establishment (2014), Solid wall heat losses and the potential for energy saving: Literature review, BRE, Watford

Building Research Establishment (2016), Solid wall heat losses and the potential for energy saving: Consequences for consideration to maximise SWI benefits: $A$ route map for change, BRE, Watford

Calì, D., Osterhage, T., Streblow, R. and Müller, D. (2016), "Energy performance gap in refurbished German dwellings: lesson learned from a field test", Energy and Buildings, Vol. 127, pp. 1146-1158.

Critchley, R., Gilbertson, J., Grimsley, M., and Green, G. (2007), "Living in cold homes after heating improvements: Evidence from Warm-Front, England's Home Energy Efficiency Scheme", Applied Energy, Vol. 84, No. 2, 147-158.

De Laurentis, C., Eames, M. and Hunt, M. (2016), "Retrofitting the built environment 'to save' energy: Arbed, the emergence of a distinctive sustainability transition pathway in Wales", Environment and Planning C: Government and Policy, DOI: 10.1177/0263774X16648332.

Department for Communities and Local Government (2016) English Housing Survey: Headline Report 2014-15, DCLG, London. 
Department of Energy and Climate Change (2011), DECC Local Authority Funds: DECC Local Authority Competition 2012-13, DECC, London.

Department of Energy and Climate Change (2013), Green Deal Communities - Local Authorities Fund Application Pack, DECC, London.

Department of Trade and Industry (2003), Our Energy Future: Creating a Low Carbon Economy, Department of Trade and Industry, London.

Dixon, T. and Wilson, E., (2013), "Cities' low-carbon plans in an 'age of austerity': an analysis of UK local authority actions, attitudes and responses", Carbon Management, Vol. 4, No. 6, pp. 663-680.

Dowson, M., Poole, A., Harrison, D., and Susman, G. (2012), "Domestic UK retrofit challenge: Barriers, incentives and current performance leading into the Green Deal”, Energy Policy, Vol. 50, pp. 294-305.

Energy Saving Trust and Technology Strategy Board (2009) Evaluating energy and carbon performance in the "Retrofit for the Future" demonstrator projects - Version 2, EST, London.

Galvin, R. (2014), "Making the "rebound effect" more useful for performance evaluation of thermal retrofits of existing homes: Defining the "energy savings deficit" and the "energy performance gap", Energy and Buildings, Vol. 69, pp. 515-524.

Guertler, P. (2012), "Can the Green Deal be fair too? Exploring new possibilities for alleviating fuel poverty", Energy Policy, Vol. 49, pp.91-97.

Guertler, P., Royston, S. and Robson, D. (2013), "Somewhere between a 'Comedy of errors' and 'As you like it'? A brief history of Britain's 'Green Deal' so far", Proceedings of the European Council for and Energy Efficient Europe Summer Study, June $3^{\text {rd }}-8^{\text {th }}$, Presqu'ile de Giens, France, ECEEE, Stockholm, pp. 153-164.

HM Government (2008), Climate Change Act 2008, London, UK.

HM Government (2010a), Warm Homes, Greener Homes: A Strategy for Household Energy Management, HM Government, London.

HM Government (2010b), Low Carbon Construction Innovation and Growth Team: Final Report, HM Government, London.

Hills, J. (2012), Getting the measure of fuel poverty: final report of the Fuel Poverty Review, Centre for Analysis of Social Exclusion, London.

Homes and Communities Agency (2012), Statistical Data Return 2011-12, HCA, London. 
Homes and Communities Agency (2015), Statistical Data Return 2014-15, HCA, London.

Hong, S., Oreszczyn, T. and Ridley, I. (2006), "The impact of energy efficient refurbishment on the space heating fuel consumption in English dwellings", Energy and Buildings, Vol. 38, No. 10, pp. 1171-1181.

Howard, R. (2015), Warmer Homes, Policy Exchange, London.

Jacobs, K., and Manzi, T. (2013), "New Localism, Old Retrenchment: The "Big Society", Housing Policy and the Politics of Welfare Reform", Housing, Theory and Society, Vol. 30, No. 1, pp. 29-45.

Jenkins, D. P. (2010), "The value of retrofitting carbon-saving measures into fuel poor social housing”, Energy Policy, Vol. 38, No. 2, pp. 832-839.

Kelly, M. J. (2009), "Retrofitting the existing UK building stock", Building Research and Information, Vol. 37, No. 2, pp. 196-200.

Kelly, M. J. (2010), "Energy efficiency, resilience to future climates and longterm sustainability: the role of the built environment", Philosophical Transactions of the Royal Society A, Vol. 368, pp. 1083-1089.

Liddell, C. and Morris, C. (2010), "Fuel poverty and human health: A review of recent evidence”, Energy Policy, Vol. 38, No. 6, pp. 2987-2997.

Lovins, A. B. (1996), "Negawatts", Energy Policy, Vol. 24, No. 4, pp. 331-343.

Mallaburn, P. S. and Eyre, N. (2014), "Lessons from energy efficiency policy and programmes in the UK from 1973 to 2013", Energy Efficiency, Vol. 7, No. 1, pp. 23-41.

McLeod, R.S., Hopfe, C.J. and Rezgui, Y. (2012), "An investigation into recent proposals for a revised definition of zero carbon homes in the UK", Energy Policy, Vol. 46, pp. 25-35.

Moore, R. (2012), "Definitions of fuel poverty: Implications for policy" Energy Policy, Vol. 49, pp. 19-26.

Muhammad-Sukki, F., Ramirez-Iniguez, R., Munir, A. B., Mohd Yasin, S. H., Abu-Bakar, S. H., McMeekin, S. G., and Stewart, B. G. (2013), "Revised feedin tariff for solar photovoltaic in the United Kingdom: A cloudy future ahead?"' Energy Policy, Vol. 52, pp. 832-838.

National Audit Office (2016), Green Deal and the Energy Company Obligation, NAO, London. 
O'Keeffe, J. M., Gilmour, D., and Simpson, E. (2016), "A network approach to overcoming barriers to market engagement for SMEs in energy efficiency initiatives such as the Green Deal”, Energy Policy, Vol. 97, 582-590.

Palmer, J. and Cooper, I. (2013), United Kingdom Housing Energy Fact File 2013, Department of Energy and Climate Change, London, UK.

Power, A. (2008), "Does demolition or refurbishment of old and inefficient homes help to increase our environmental, social and economic viability?", Energy Policy, Vol. 36, No. 12, pp. 4487-4501.

Ravetz, J., (2008), "State of the stock—What do we know about existing buildings and their future prospects?", Energy Policy, Vol. 36, No. 12, pp. 4462-4470.

Reeves, A., Taylor, S., and Fleming, P. (2009), "Deep carbon emission reductions in existing UK social housing: are they achievable, and how can they be funded?", Proceedings of the European Council for and Energy Efficient Europe Summer Study, June $1^{\text {st }}-6^{\text {th }}$, La Colle sur Loup, France, ECEEE, Stockholm, pp. 919-930.

Reeves, A., Taylor, S., and Fleming, P. (2010), "Modelling the potential to achieve deep carbon emission cuts in existing UK social housing: The case of Peabody", Energy Policy, Vol. 38, No. 8, pp. 4241-4251.

Robson, C. (2002) Real World Research, 2nd Edition, Blackwell, Malden, MA., USA.

Rosenow, J. and Eyre, N. (2012), "The Green Deal and the Energy Company Obligation-will it work?", 9th British Institute of Energy Economics Academic Conference - European Energy in a Challenging World: The Impact of Emerging Markets, $19^{\text {th }}-20^{\text {th }}$ September 2012, St John's College Oxford, BIEE, London.

Rosenow, J., Platt, R., and Flanagan, B. (2013), "Fuel poverty and energy efficiency obligations - A critical assessment of the supplier obligation in the UK", Energy Policy, Vol. 62, pp. 1194-1203.

Rosenow, J. and Eyre, N. (2016), "A post mortem of the Green Deal: Austerity, energy efficiency, and failure in British energy policy", Energy Research \& Social Science, Vol. 21, pp.141-144.

Smith, A., Kern, F., Raven, R., and Verhees, B. (2014), "Spaces for sustainable innovation: Solar photovoltaic electricity in the UK", Technological Forecasting and Social Change, Vol. 81, pp. 115-130.

Snape, J. R., Boait, P. J., and Rylatt, R. M. (2015), "Will domestic consumers take up the renewable heat incentive? An analysis of the barriers to heat pump adoption using agent-based modelling", Energy Policy, Vol. 85, pp. 3238. 
Stewart, J. and Dhesi, S. (2016), "Affordable warmth: housing strategies for older people", Housing, Care and Support, Vol. 19, No. 1, pp. 23-31.

Swan, W., Fitton, R., and Brown, P. (2015), "A UK practitioner view of domestic energy performance measurement", Proceedings of the Institution of Civil Engineers - Engineering Sustainability, Vol. 168, No. 3, pp. 140-147.

Swan, W., Ruddock, L., Smith, L., and Fitton, R. (2013a), "Adoption of sustainable retrofit in UK social housing", Structural Survey, Vol. 31, pp. 181193.

Swan, W., Ruddock, L. and Smith, L. (2013b), "Low carbon retrofit: attitudes and readiness within the social housing sector", Engineering, Construction and Architectural Management, Vol. 20, No. 5, pp. 522-535.

Taylor-Gooby, P. (2012), "Root and Branch Restructuring to Achieve Major Cuts: The Social Policy Programme of the 2010 UK Coalition Government", Social Policy and Administration, Vol. 46, No. 1, pp. 61-82.

Taylor, T., Counsell, J., and Gill, S. (2013), "Energy efficiency is more than skin deep: Improving construction quality control in new-build housing using thermography", Energy and Buildings, Vol. 66, pp. 222-231.

Tovar, M.A. (2012), "The structure of energy efficiency investment in the UK households and its average monetary and environmental savings", Energy Policy, Vol. 50, pp. 723-735.

Walker, G. and Day, R. (2012), "Fuel poverty as injustice: Integrating distribution, recognition and procedure in the struggle for affordable warmth", Energy Policy, Vol. 49, pp. 69-75.

Wetherell, S. and Hawkes, J. (2011), "Are SAP based assessments an accurate way of predicting the energy savings made through refurbishment?", 'Buildings don't use energy, people do?' Research Students' Conference on Domestic Energy Use and $\mathrm{CO}_{2}$ Emissions in Existing Dwellings Bath $28^{\text {th }}-29^{\text {th }}$ June 2011, University of Bath, Centre for Alternative Technology, Bath, pp. 43-54. 